\title{
Ectonucleotide Pyrophosphatase/Phosphodiesterase Family Member 2
}

National Cancer Institute

\section{Source}

National Cancer Institute. Ectonucleotide Pyrophosphatase/Phosphodiesterase Family

Member 2. NCl Thesaurus. Code C104211.

Ectonucleotide pyrophosphatase/phosphodiesterase family member 2 (863 aa, 99 kDa)

is encoded by the human ENPP2 gene. This protein plays a role in cell growth, survival,

migration and angiogenesis. 